\title{
Review \\ Cancer and SARS-CoV-2 Infection: Diagnostic and Therapeutic Challenges
}

\author{
Alessandro Allegra ${ }^{1,2, *} \mathbb{\infty}$, Giovanni Pioggia ${ }^{3}$, Alessandro Tonacci ${ }^{4}{ }^{\circledR}$, Caterina Musolino $^{1}$ and \\ Sebastiano Gangemi ${ }^{5}$ \\ 1 Division of Haematology, Department of Human Pathology in Adulthood and Childhood "Gaetano Barresi", \\ University of Messina, 98125 Messina, Italy; cmusolino@unime.it \\ 2 COVID Centre AOU Policlinic G. Martino Messina, 98125 Messina, Italy \\ 3 Institute for Biomedical Research and Innovation (IRIB), National Research Council of Italy (CNR), \\ 98164 Messina, Italy; giovanni.pioggia@cnr.it \\ 4 Clinical Physiology Institute, National Research Council of Italy (IFC-CNR), 56124 Pisa, Italy; \\ atonacci@ifc.cnr.it \\ 5 School and Operative Unit of Allergy and Clinical Immunology, Department of Clinical and \\ Experimental Medicine, University of Messina, 98125 Messina, Italy; gangemis@unime.it \\ * Correspondence: aallegra@unime.it; Tel.: +390902212364
}

Received: 27 May 2020; Accepted: 10 June 2020; Published: 15 June 2020

check for updates

\begin{abstract}
In late December 2019, a new infectious viral disease appeared. A new betacoronavirus, severe acute respiratory syndrome coronavirus 2 (SARS-Cov-2), has been recognized as the pathogen responsible for this infection. Patients affected by tumors are more vulnerable to infection owing to poor health status, concomitant chronic diseases, and immunosuppressive conditions provoked by both the cancer and antitumor therapies. In this review, we have analyzed some lesser known aspects of the relationship between neoplasms and SARS-CoV-2 infection, starting from the different expression of the ACE2 receptor of the virus in the various neoplastic pathologies, and the roles that different cytokine patterns could have in vulnerability to infection and the appearance of complications. This review also reports the rationale for a possible use of drugs commonly employed in neoplastic therapy, such as bevacizumab, ibrutinib, selinexor, thalidomide, carfilzomib, and PD-1 inhibitors, for the treatment of SARS-CoV-2 infection. Finally, we have highlighted some diagnostic challenges in the recognition of SARS-CoV-2 infection in cancer-infected patients. The combination of these two health problems-tumors and a pandemic virus-could become a catastrophe if not correctly handled. Careful and judicious management of cancer patients with SARS-Cov-2 could support a better outcome for these patients during the current pandemic.
\end{abstract}

Keywords: cancer; SARS-CoV-2; COVID-19; epidemiology; treatment; prognosis; risk factor; immunosuppression; cytokines

\section{Introduction}

The World Health Organization (WHO) has lately stated that the present pandemic of coronavirus disease 2019 (COVID-19) is a public health crisis of international interest [1]. As of May 27-5,500,000 COVID-19 infected patients had been registered globally, and more than 300,000 people had died from the virus, now known as severe acute respiratory syndrome coronavirus 2 (SARS-CoV-2).

With more than 18 million new cases per year worldwide, cancer affects a considerable proportion of the global population, and subjects affected by tumors are more vulnerable to infections owing to poor health status, concomitant chronic diseases, and immunosuppressive conditions provoked by both the tumors and antitumor therapies [2,3]. In addition, apart from altered host defenses, 
other factors, such as leukopenia, disturbance to the barriers to infection, and changes in microbial flora, could be important [4-6].

As a consequence, patients with tumors who are infected by the SARS-CoV-2 coronavirus may suffer worse outcomes than other subjects. In fact, in a previous outbreak of a related virus which gave rise to the Middle East Respiratory Syndrome epidemic in 2015, a mortality rate of $84 \%$ was observed in tumor-affected subjects, which was twice as high as the rate in non-oncology subjects [7].

Similarly, throughout the influenza A virus subtype H1N1 (H1N1) epidemic in 2009, mortality for cancer subjects hospitalized with H1N1 was up to $18.5 \%$ higher [8]. However, although the H1N1 epidemic was protracted, it did not have the same impact as the SARS-CoV2 epidemic appears to be having, nor was it as fatal.

It has been predicted that at least 6270 supplementary deaths could occur in England over the next 12 months in subjects with new tumor diagnoses, as an effect of the SARS-CoV-2 outbreak [9].

\section{Incidence and Severity of SARS-CoV2 Infection in Cancer Patients}

According to analyses of subjects receiving treatment for SARS-CoV-2 in Chinese hospitals, those with tumors appear to be at greater risk of infection and tend to have less positive prognoses.

Liang et al. reported on 2007 cases from 575 hospitals. A total of 18 (1\%) of 1590 SARS-CoV-2 subjects had a history of tumors, which is higher than the occurrence of tumors in the general Chinese population $(0.29 \%)$. Lung tumors were the most common form $(28 \%)$. Of the subjects with tumors and SARS-CoV-2, $25 \%$ had been subjected to chemotherapy or surgery within the past month, while $75 \%$ of subjects were cancer survivors in follow up after resection. Compared to subjects without tumors, subjects with tumors were older (mean age 63.1 years vs. 48.7 years), had more polypnea ( $47 \%$ vs. $23 \%$ ), were more likely to have a history of smoking ( $22 \%$ of patients vs. $7 \%$ ), and had more severe baseline computed tomography signs ( $94 \%$ vs. $71 \%$ ). There were no relevant variations in comorbidities, sex, or baseline gravity of X-rays. Most notably, subjects with tumors had a greater risk of critical incidents (patients admitted to an intensive care unit (ICU), invasive ventilation, or death) with respect to subjects without tumors (39\% vs. $8 \%$ ). These data were validated by logistic regression after adjusting for other risk factors. Cancer history was the greater risk factor for critical events. Among subjects with tumors, older age was a risk factor for critical events. Subjects with lung tumors did not have a greater possibility of critical events with respect to subjects with different tumor forms. Moreover, utilizing a Cox regression model to analyze the time-dependent risk of developing critical events, it was demonstrated that subjects with tumors worsened more quickly than those without tumors (median time to critical events: 13 vs. 43 days [10] (Table 1)).

Table 1. Incidence and severity of severe acute respiratory syndrome coronavirus 2 (SARS-CoV-2) in cancer patients worldwide.

\begin{tabular}{|c|c|c|}
\hline Study & Subjects & Findings \\
\hline \multicolumn{3}{|c|}{ All/various countries/continents } \\
\hline $\begin{array}{l}\text { Worldometer (2020) } \\
\text { [11] }\end{array}$ & $\begin{array}{l}\text { All confirmed worldwide } \\
\text { cases ( }>5 \text { million) }\end{array}$ & $\begin{array}{l}\text { Critical events in } 48-54 \% \text { of cancer patients vs. } 16 \% \text { in } \\
\text { general population; death in } 5.6-29 \% \text { vs. } 3.4 \%\end{array}$ \\
\hline $\begin{array}{l}\text { Hrusak et al. (2020) } \\
\text { Various countries [12] }\end{array}$ & $\begin{array}{l}\text { 10,000, of which } 2000 \\
\text { children analyzed }\end{array}$ & $\begin{array}{c}4.5 \% \text { with tumor, of which } 88.9 \% \text { asymptomatic or } \\
\text { mildly symptomatic }\end{array}$ \\
\hline \multicolumn{3}{|r|}{ Asia } \\
\hline $\begin{array}{l}\text { Liang et al. (2020) } \\
\text { China [10] }\end{array}$ & 2007 & $\begin{array}{l}\text { Tumor history in SARS-CoV vs. general population: } 1 \% \\
\text { vs. } 0.29 \% \\
\text { Subjects with tumor worsened more quickly (13 vs. } 43 \\
\text { days until critical events) and were more critical } \\
(39 \% \text { vs. } 8 \%)\end{array}$ \\
\hline
\end{tabular}


Table 1. Cont.

\begin{tabular}{|c|c|c|}
\hline Study & Subjects & Findings \\
\hline $\begin{array}{l}\text { Yu et al. (2020) } \\
\text { China [13] }\end{array}$ & 1524 & $\begin{array}{c}0.79 \% \text { with tumor in SARS-CoV } \\
25 \% \text { of those with tumor had severe respiratory } \\
\text { syndrome, } 8.3 \% \text { were admitted to intensive care } \\
\text { unit (ICU) }\end{array}$ \\
\hline $\begin{array}{l}\text { Chen et al. (2020) } \\
\text { China [14] }\end{array}$ & 99 & $\begin{array}{l}\text { Tumor history in SARS-CoV vs. general population: } \\
1 \% \text { vs. } 0.2 \%\end{array}$ \\
\hline $\begin{array}{l}\text { Deng et al. (2020) } \\
\text { China [15] }\end{array}$ & 44,672 & $\begin{aligned} \text { Relative Risk } & =2.926 \text { for tumors as risk factors for fatality } \\
& \text { of patients with COVID-19 }\end{aligned}$ \\
\hline $\begin{array}{l}\text { WHO (2020) } \\
\text { China [1] }\end{array}$ & 75,465 & $\begin{array}{l}7.6 \% \text { of mortality for cancer patients, fifth highest after } \\
\text { cardiovascular disease }(13.2 \%) \text {, diabetes }(9.2 \%), \\
\text { hypertension }(8.4 \%) \text {, chronic respiratory disease }(8.0 \%)\end{array}$ \\
\hline $\begin{array}{l}\text { He et al. (2020) } \\
\text { China [16] }\end{array}$ & 354 & $\begin{array}{c}10 \% \text { with tumor in SARS-CoV-2 in general public }(7 \% \text { in } \\
\text { healthcare providers) } \\
\text { More severe SARS-CoV in patients with } \\
\text { haematological diseases }\end{array}$ \\
\hline \multicolumn{3}{|c|}{ Europe } \\
\hline $\begin{array}{l}\text { Palmieri et al. (2020) } \\
\text { Italy [17] }\end{array}$ & 37,860 & $20 \%$ with tumor in SARS-CoV-2 \\
\hline $\begin{array}{l}\text { Onder et al. (2020) } \\
\text { Italy [18] }\end{array}$ & 355 & $\begin{array}{l}20.3 \% \text { with tumor in SARS-CoV-2 } \\
\text { Mortality }=20 \% \text { of subjects with tumor older than } 80\end{array}$ \\
\hline $\begin{array}{l}\text { Balduzzi et al. (2020) } \\
\text { Italy [19] }\end{array}$ & 5 children & $100 \%$ survival ( $60 \%$ were paucisymptomatic) \\
\hline \multicolumn{3}{|c|}{ Americas } \\
\hline $\begin{array}{l}\text { Miyashita et al. (2020) } \\
\text { USA [20] }\end{array}$ & 5688 & $\begin{array}{c}\text { 6\% with tumor in SARS-CoV } \\
\text { Higher complications, higher mortality in younger } \\
\text { patients with cancer }\end{array}$ \\
\hline
\end{tabular}

In an analogue study, Yu et al. calculated the infection percentage of SARS-CoV-2 in subjects with tumors from a single institution at $0.79 \%$ (12 of 1524 patients). Seven of the 12 (58.3\%) subjects had non-small cell lung carcinomas (NSCLC). Five (41.7\%) were being given chemotherapy with or without immunotherapy or radiotherapy. Three patients $(25.0 \%)$ had a severe respiratory syndrome; one subject needed to be admitted to the intensive care unit [13].

These data were confirmed by Chen's paper, which proposed that among those infected with SARS-CoV-2, about $1 \%$ of subjects had tumors (3): this was 5 -fold greater than the overall occurrence of cancer in China (201.7/100,000 persons) [14,21].

Other authors have re-analyzed the greatest case series described by the Chinese center for disease control and prevention (44,672 cases), to evaluate the clinical risk factors correlated with death. Tumors $(\mathrm{RR}=2.926,95 \% \mathrm{CI}=1.34-6.41)$ were the main risk factors for mortality of subjects with SARS-CoV-2 [15].

A similar multi-center analysis was performed by Dai et al., employing subject information gathered from 14 hospitals in Hubei Province, China, in which they reported the clinical features and outcomes (development of severe respiratory syndrome, invasive mechanical ventilation, ICU admission, and death) of infected patients for 105 hospitalized subjects with tumors and 536 subjects without tumors. The data demonstrated SARS-CoV-2 subjects with cancer had greater risks for all severe outcomes. Subjects with hematological neoplasia, lung cancer, or metastatic cancer had the greatest incidence of critical events. Non-metastatic cancer subjects presented with similar rates of critical events to subjects without tumors. Patients who received surgery had higher risks of having critical events, while subjects submitted only to radiotherapy did not display relevant differences in critical events with respect to patients without cancer [22]. 
An updated WHO report reported a mortality of $7.6 \%$ among patients with cancer [1], while according other studies, cancer subjects are at a higher risk of critical events in $(48-54 \%$ of cases vs. $16 \%$ in the general population) and death (5.6-29\% vs. $3.4 \%$ in the general population) [11].

The results on the frequency of SARS-CoV-2 infection in tumor subjects seem diverse, and effects greater than those reported so far may be found when this is evaluated in other geographic areas. Miyashita et al. examined the electronic medical records (EMR) of Mount Sinai Health System (MSHS) in New York City from 1 March to 6 April, 2020, using Epic SlicerDicer software. They evaluated relevant clinical and demographic information (age, sex, comorbidities, critical events, and death rate) from 5688 patients with SARS-CoV-2, and found 334 subjects $(6 \%)$ with tumors in this group (57 breast, 56 prostate, 23 lung, 18 urothelial, and 16 colon cancer). Without correcting for age groups, subjects with tumors were intubated considerably more frequently, but the death rate was not significantly different. After stratifying subjects by age, they demonstrated a significantly augmented risk of intubation in subjects with tumors if aged 66-80. Unexpectedly, subjects with tumors who were younger than 50 years had a higher mortality percentage. Moreover, the mortality of SARS-CoV-2 in tumor subjects was lower than that in subjects without tumors in age groups older than 50 years, although the difference was not statistically significant. The uncertain connection between SARS-CoV-2 and intubation or death is a drawback in this analysis. Moreover, the heterogeneity of tumor forms and diverse stages of cancers may provoke some uncertainty in the interpretation of the data [20].

In contrast to data from China and the USA, a report from Italy suggested that $20 \%$ of subjects with SARS-CoV-2 had been treated for a tumor in the previous 5 years. However, in this study, the detection of comorbidities was limited to subjects who died of SARS-CoV-2; therefore, differentiating between tumors as an independent risk factor for developing SARS-CoV-2 or as a risk factor for a bad prognosis is not possible [17].

In a different study performed on 355 Italian subjects, $20.3 \%$ had an active tumors, in addition to several other comorbidities. Although a higher mean age (79.5 \pm 8.1 years) was registered within this group, separate analyses have demonstrated a death percentage estimated at $20 \%$ in subjects aged 80 and older [18].

A specific analysis was performed on particular subsets of patients, such as those affected by onco-hematological pathologies. One might suppose subjects with immune system tumors, such as lymphomas and lymphoid leukemias, might be at augmented risk for contracting SARS-CoV2 with respect to patients with myeloid cancers, such as Acute Myeloid Leukemia and Myelodysplastic Syndromes (AML and MDS), but an evaluation found no such connection. He et al. performed a cohort study at two centers in Wuhan, China, of 128 hospitalized patients with hematological neoplasia, $10 \%$ of whom contracted SARS-CoV-2, and of 226 health care providers, 16 of whom contracted SARS-CoV-2 and 11 of whom were hospitalized. The case rate for SARS-CoV-2 in hospitalized subjects with hematological diseases was $10 \%$, compared to $7 \%$ in health care providers. Nevertheless, the 13 patients with hematological diseases had more serious SARS-CoV-2, and more from this group died from the illness. The case fatality percentages were $62 \%$ and $0 \%$, respectively [16].

The augmented case fatality rate of patients with hematological disorders and SARS-CoV-2 appears to be correlated essentially to bacterial infections. This is consistent with a greater possibility of reduced granulocyte levels because of their disease or treatment.

Regarding the gravity of the infection in cancer patients and the high mortality rate in cancer patients, it should be borne in mind that patients with SARS-CoV-2 may struggle to overcome critical phases such as intubation; full intensive care support and life sustaining therapies cannot overcome the poor prognosis for certain high-risk populations affected by SARS-CoV-2 [23-25].

A separate discussion must then be had in the field of pediatric oncology. Hrusak et al. performed a flash survey on SARS-CoV-2 occurrence and gravity among children on antitumor treatments. They collected data from 25 countries, and about 10,000 patients considered at risk were followed. Over 200 of these children were tested, nine of whom were positive for SARS-CoV-2. Eight of the nine cases had an asymptomatic to mild infection [12]. 
The low percentage of infection in this population is rather unexpected, as it is reasonable to presume that pediatric subjects with tumors would be at least as vulnerable to infection as their healthy peers. SARS-CoV-2 does infect children in general, although the minor gravity of the infection increases the likelihood of underreporting in children.

The mild infection experienced by three children in this report was in contrast to a formerly reported case. An 8 year old child undergoing myelosuppressive chemotherapy for T-cell acute lymphoblastic leukemia in ALL in a Wuhan hospital presented with respiratory failure, necessitating mechanical ventilation. During the disease, CRP and Interleukin (IL)-6) were only slightly increased, but ferritin concentrations were elevated $(6417-15,758 \mathrm{ug} / \mathrm{L})$. This is evocative of characteristics of hemophagocytic lymphohistiocytosis, which has been reported to co-occur with infections [26].

A description of the Italian experience at a major childhood cancer center in Lombardy has recently been presented [19]. This report described five positive cases in subjects with childhood tumors, all of whom had a benign course and survived. Three subjects were treated at home, and two in hospital.

As for a possible explanation for the different course that tends to occur in children, the quantitative and qualitative changes in cytokine delivery can cause a diverse immune responses, and may explain the diverse outcomes in specific patients. In fact, it has now been documented that pregnant women and children generally have a mild disease after SARS-CoV-2 infection, if not a fully asymptomatic one [27]. These types of subjects have an immune response skewed toward a T-helper Type 2 cells (TH2) profile (controlled by the TH2 cells), with a particular production of cytokines like IL- 4 and IL-10, while production of the pro-inflammatory cytokines in SARS-CoV-2 infection is characteristic of TH1 cells.

This specific immunological setup could somewhat defend pediatric tumor subjects from the most critical clinical manifestations of the infection.

Despite the presence in the literature of sometimes discordant data, this discordance can probably be linked to the low number of samples collected, the heterogeneity of neoplastic pathologies, and ethnic differences. It is likely that cancer patients have a different susceptibility to SARS-CoV-2 infection, a different course, and a different prognosis.

\section{Pathophysiology of SARS-CoV 2 Infection in Cancer Patients}

The present data remain inadequate to explicate an irrefutable correlation between tumors and SARS-CoV2 infection or poorer outcomes. However, some considerations and hypotheses can be formulated on the subject (Figure 1).

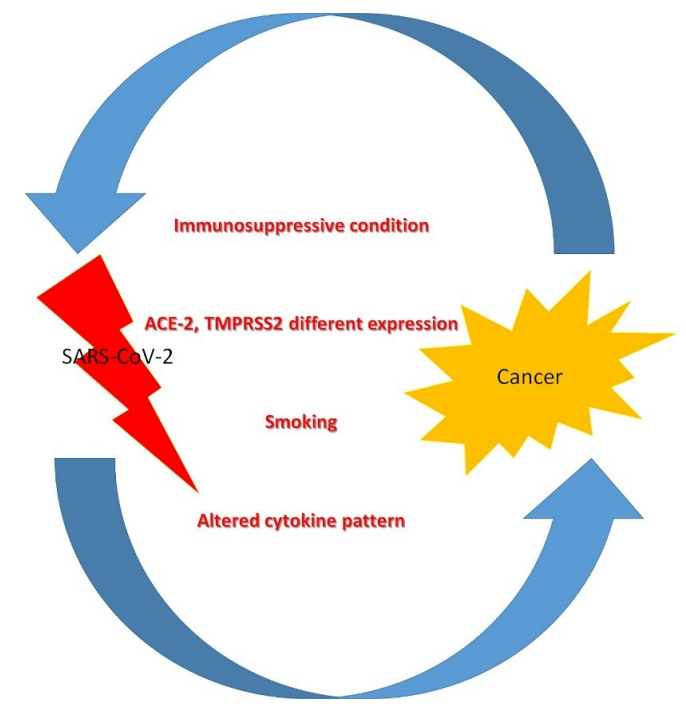

Figure 1. Pathophysiology of severe acute respiratory syndrome coronavirus 2 (SARS-CoV-2) infection in cancer patients. 
SARS-CoV2's cellular entry receptor, angiotensin-converting enzyme 2 (ACE2) [28], may be overexpressed in some tumors, including in pancreatic, cervical, and renal cancers [29]. However, other experiments have suggested the expression of ACE2 is considerably reduced in prostate, liver, and breast tumors, with respect to normal contiguous tissues.

Specific studies have been conducted in patients with renal papillary cell carcinoma and endometrial cancer.

ACE2 is a component of the renin-angiotensin system, however the relationship between ACE2 and prognosis in UCEC (uterine corpus endometrial carcinoma) and KIRP (kidney renal papillary cell carcinoma) is not well-defined. ACE2 is augmented in KIRP and UCEC, and increased ACE2 is associated with a favorable outcome. The expression of ACE2 appears to be positively correlated with the amount of immune infiltration of macrophages in KIRP, CD4+T cells, B cells, neutrophils, and dendritic cell immune infiltration in UCEC. Increased ACE2 expression is correlated with a favorable prognosis in UCEC and KIRP. What is more, it has been demonstrated that the expression of ACE2 is reduced in vivo and in vitro after SARS-Co-V2 infection. In conclusion, cancer may make sufferers more vulnerable to SARS-CoV-2 infection in the cases of KIRP and UCEC, leading to a poorer prognosis [30].

Similar studies have been conducted in lung cancer, as these patients appear to be more susceptible to infection than normal subjects [31].

The gene expression level of ACE2 may indicate susceptibility to SARS-CoV-2 infection. Transmembrane serine protease 2 (TMPRSS2) has a supportive action.

In fact, SARS-CoV-2 infected hACE2 transgenic mice showed serious pulmonary alterations, comprising interstitial hemorrhage, protein exudation, lymphocytic infiltration, and alveolar epithelial cell growth [32]. SARS-CoV-2 infected TMPRSS2-KO mice displayed reduced inflammatory cytokine reactions to intranasal stimulation. TMPRSS2 reduction modified the primary sites of infection and the virus spread within the airways, leading to a less critical immunopathology [33].

In another study, the correlation between gene expression of ACE2 and TMPRSS2 and outcomes in lung adenocarcinoma (LUAD) and lung squamous cell carcinoma (LUSC) was explored [34]. Lung tumor subjects in each subtype and stage were found to be predisposed to SARS-CoV-2 infection, excluding the primitive subtype of LUSC. LUAD subjects are more vulnerable to SARS-CoV-2 infection than LUSC subjects. TMPRSS2 may be a tumor suppressor gene, as it was severely reduced in LUAD and LUSC.

Indeed, the relationship between ACE2, cancer, and smoking may have importance, and a diverse possible justification for different vulnerabilities and outcomes in lung cancer subjects might be the greater smoking history in these patients [35]. Experimental findings have demonstrated that tobacco use considerably augments the gene expression of ACE2, which could lead to increased susceptibility to SARS-CoV2 in smokers [36]. Moreover, cigarette smoking is the main cause of chronic obstructive pulmonary disease, which has been recognized as an independent risk factor in critical SARS-CoV2 patients $[37,38]$.

In addition to the above, although not all tumor subjects should be considered equally immunocompromised, tumors are always connected with an increased expression of immunosuppressive cytokines, decreased pro-inflammatory danger signals, and an augmented functional immunosuppressive leukocyte population, which may cause a dampened immune system and augment the probability of infectious complications [39].

Some specific cytokines may favor SARS-CoV2 infection, and at the same time have a role in neoplastic diseases. For instance, IL-17 could be central to this process. In the lung, the IL-17 cytokine is generated by TH17 cells in reaction to viruses. IL-17 stimulates signaling, which in turn induces the production of chemokines. These substances enroll immune system cells to the inflammation site. The permanency of the virus causes a hyperactivity of the immune system which can provoke a cytokine storm [40], and IL-17 stimulates, in synergy with IL-6, viral permanency by stopping apoptosis [41]. Other research has found that it is possible to clarify the biological mechanisms correlated with organ 
injury due to virus action via the IL-17 pathway [41]. In addition to provoking a cytokine storm and blocking the programmed cell death of infected cells, it also appears to have the capability to augment the proliferation of some viruses by augmenting their virulence [42]. It has further been reported, in an experimental model, that viral persistence, by producing a persistent augmentation of IL-17, provokes ARDS (acute distress respiratory syndrome) [43], just as it occurs in SARS-CoV-2 infection. The augmented concentration of IL-17 could also be correlated with the hypercoagulation condition sometimes seen in SARS-CoV-2 subjects [44].

Moreover, an elevated amount of TH17 lymphocytes released into the alveolar space has been described. At the same time, the role of IL-17 is well known in lung cancer, as IL-17 stimulates VEGF production in cancer cell lines [45]. This action is supported by the STAT3-G $\alpha-$ Interacting Vesicle-Associated Protein (GIV) pathway, and is stopped when cells are exposed to small interfering RNA (siRNA) [46]. It has been reported that patients with augmented concentrations of IL-17 were less likely to survive and had increased angiogenesis with respect to healthy controls [47]. Similarly, exposure of diverse NSCLC cell lines to IL-17 increased neo-angiogenesis and augmented in vivo cancer proliferation in SCID mice via a C-X-C chemokine receptor (CXCR-2)-dependent mechanism. In fact, IL-17 increased numerous pro-angiogenic CXC chemokines, including CXCL1, CXCL5, CXCL6, and CXCL8. Blocking IL-17 with monoclonal antibodies abrogated this up-regulation, and could be theoretically advantageous in subjects with SARS-CoV-2 infection.

Anti-IL-17 use is well established and approved in psoriatic arthritis, and has demonstrated a therapeutic action not only in several tumor forms [48], but also in the therapy of lung infections due to the H1N1 virus [47], ARDS [49], and pulmonary fibrosis [50]. If a study was able to determine that IL17 target therapy can both control tumor diseases and lead to resolution of SARS-CoV-2 infection, it could be applied as a treatment for SARS-CoV-2 patients with lung cancer [51].

\section{Diagnostic Challenges in the Recognition of SARS-CoV-2 Infection and Neoplastic Disease in Cancer-Infected Patients}

The presence of a neoplastic disease can complicate some diagnostic elements of SARS-CoV-2 infection, such as respiratory distress syndrome. Both SARS-CoV-2 and tumor non-SARS-CoV-2 conditions, such as superior vena cava obstruction, lung metastasis, or upper airway tumors, can provoke breathlessness and distress. The presenting characteristics of SARS-CoV-2, such as fever, fatigue, and dyspnea, are frequently analogous to those of subjects with tumors, particularly those undergoing therapy. Therefore, the identification of SARS-CoV-2 symptoms in such subjects can be difficult (Table 2).

Table 2. Common features, markers and clinical characteristics between SARS-CoV-2 and tumor non-SARS-CoV-2.

\begin{tabular}{ccc}
$\begin{array}{c}\text { Common Features of } \\
\text { SARS-CoV-2 and Tumor } \\
\text { non-SARS-CoV-2 }\end{array}$ & $\begin{array}{c}\text { Common Markers of SARS-CoV-2 } \\
\text { and Tumor non-SARS-CoV-2 }\end{array}$ & $\begin{array}{c}\text { Other Clinical Characteristics } \\
\text { Common in SARS-CoV-2 and } \\
\text { Tumor non-SARS-CoV-2 }\end{array}$ \\
\hline $\begin{array}{c}\text { Superior vena cava obstruction } \\
\text { Lung metastasis }\end{array}$ & $\begin{array}{c}\text { Carbohydrate antigens } \\
\text { Carcinoembryonic antigen }\end{array}$ & \\
Upper airway tumors & $\begin{array}{c}\text { Human epididymis protein } 4 \\
\text { Breathlessness }\end{array}$ & Hematologic malignancies \\
Distress & $\begin{array}{c}\text { Cytokeratin-19 fragment CYFRA21-1 } \\
\text { Fever }\end{array}$ & $\begin{array}{c}\text { Squamous cell carcinoma antigen } \\
\text { (only critical cases) }\end{array}$ \\
Fatigue & & \\
Dyspnea & & \\
\hline
\end{tabular}

Not only can the clinical appearance of SARS-CoV-2 in tumor subjects be unique, but identifying this disease is problematic due to several factors. For instance, tumor subjects might have atypical radiographic features. $\mathrm{Qu}$ et al. A study described the case of one subject affected by lung 
adenocarcinoma who had a laboratory established SARS-CoV-2 infection with irregular, diffuse, small ground-glass opacities and partial consolidation on chest CT-scan. This is not congruent with the typical peripheral subpleural ground-glass infiltrates seen in this infection [52]. Lung tumor subjects might have radiographic features alike to those of a SAR-CoV-2 infection, and this might be misleading. A study described the cases of five of 139 tumor subjects who had ground-glass opacities on baseline chest CT-scans. Three of these subjects submitted to RT-PCR, had a negative test, and were judged negative for SARS-CoV-2 [53].

Moreover, many cancer markers, such as carbohydrate antigens (CA) and carcinoembryonic antigens (CEA), increase during several inflammatory situations in the lungs. Wei et al. postulated that SARS-CoV-2-provokes acute lung damage, which may be accompanied with augments of some tumor markers [54]. In this retrospective analysis, the concentrations of several serum biomarkers were performed in SARS-CoV-2 subjects (mild: 131; severe: 98; critical: 23). They reported that there were relevant augments in concentrations of carcinoembryonic antigen (CEA), carbohydrate antigens (CA) 125 and 153, human epididymis protein 4 (HE4), and cytokeratin-19 fragment (CYFRA21-1) in SARS-CoV-2 mild cases with respect to normal controls; their concentrations exhibited constant and relevant augments in severe and critical cases. CA199 and squamous cell carcinoma antigen (SCC) are augmented considerably only in critical cases of SARS-CoV-2, with respect to mild and severe cases and normal controls. There were positive correlations between concentrations of C-reactive protein and concentrations of CEA, SCC, HE4, CYFRA21-1, CA153, and CA125 [54]. In this analysis, the authors excluded any subjects with tumor diagnoses; therefore, the increase of these cancer markers was not correlated with pre-existing situations of tumorigenesis. Moreover, numerous previous studies have established that cancer biomarkers are also elevated in various inflammatory conditions in the lungs [55-60] (Table 2).

Finally, other biological and clinical characteristics can disguise SARS-CoV-2's presentation in tumor subjects. For instance, hematologic malignancies can cause laboratory results to be misleading.

The presence of one of the two pathologies, or both in the same subject, can therefore make the diagnostic process more difficult.

\section{Antineoplastic and Antiviral Therapy in Infected Patients with Neoplasia}

The aim of this review was not to analyze in detail the therapy of individual neoplastic pathologies in patients with SARS-CoV-2, nor to suggest how the presence of infection should change the approach to neoplastic disease. As we will briefly mention later, specific national and international oncology societies have issued dozens of comprehensive guidelines capable of guiding the diagnostic, therapeutic, and follow-up interventions of health professionals. In the next paragraphs we will evaluate instead those drugs used in the oncology field that can interfere with the clinical evolution of SARS-CoV-2 infection (Figure 2).

For instance, Chinese trials are currently evaluating the action of the anti-vascular endothelial growth factor (VEGF) bevacizumab on SARS-CoV-2 patients (NCT04275414). VEGF is the most potent vascular permeability inducer, and higher levels of VEGF have been found in SARS-CoV-2 patients compared with healthy controls. Other studies will try to evaluate the effects of drugs, such as the myeloma drug thalidomide (NCT04273581), the programmed death-1 (PD-1) inhibitor camrelizumab (NCT04268537), and other anti-TNF tNFkumor drugs in the therapy of SARS-CoV-2 infection. The possible value of other targeted substances, such as carfilzomib, afatinib, and ixazomib, will also be assessed [61].

Regarding molecules that target the immune check points PD-1 and its ligand (PD-L1), these drugs have changed the therapy and outcome of numerous forms of tumors. These monoclonal antibodies are able to restore antitumor immunity, and have received approval for the treatment of several forms of tumors, including lung cancer, breast cancer, melanoma, and urological tumors [62-65]. 


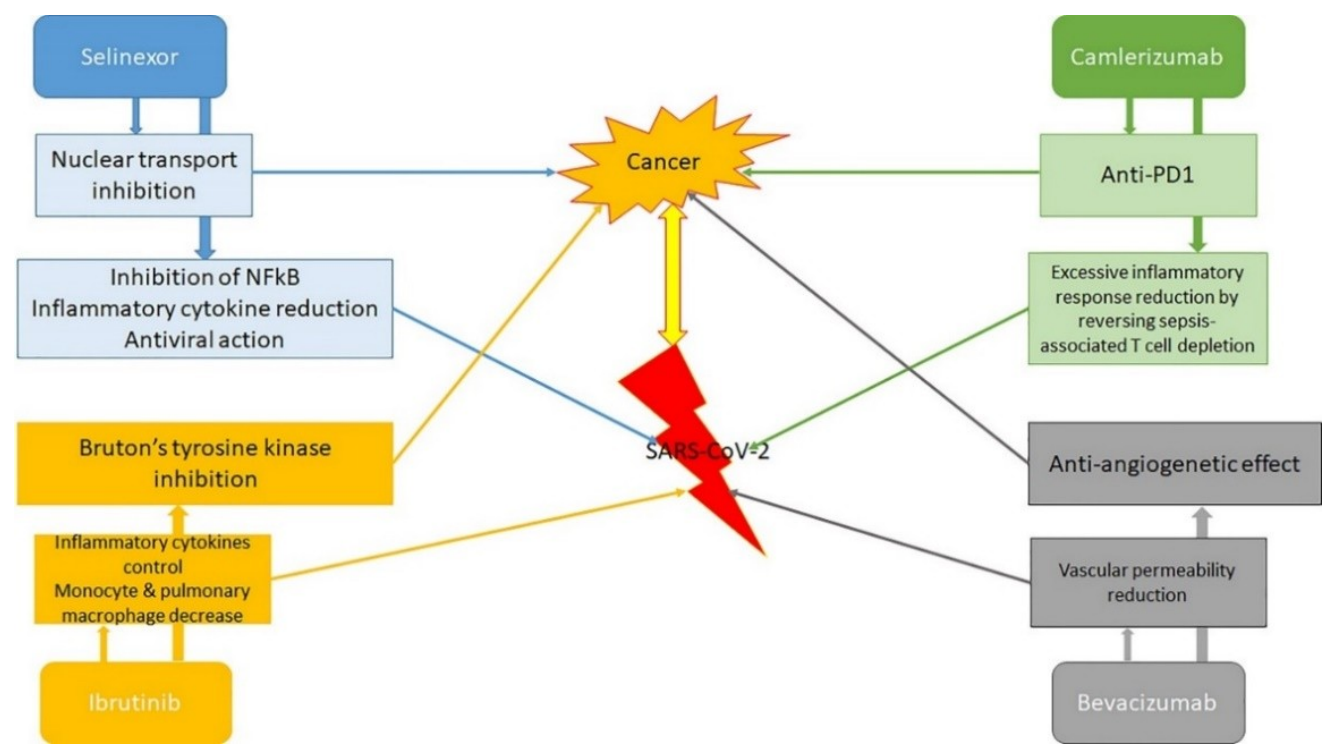

Figure 2. Antineoplastic and antiviral actions of drugs commonly used in various neoplastic diseases. PD-1: programmed death-1.

The immune-related adverse events (irAEs) of anti-PD-1 or anti-PD-L1 substances are generally inflammation against organ-specific targets. Patients can present with irAEs such as pneumonitis, hepatitis, myocarditis, nephritis, and encephalitis. There is no augmented occurrence of hepatitis in patients with chronic hepatitis or immune reconstitution in subjects with HIV infection [66,67]. However, there have been cases of reactivation of latent tuberculosis via an augment in the immune response [68]. Reports of fatal encephalitis or myocarditis found in Epstein-Barr virus positive lymphocytes in the affected histological region have been released, suggesting some role of the infection in this irAE [69]. However, differently to chemotherapy, which is immunosuppressive, immune checkpoint inhibitors may be a safer possibility, as one case series of tumor subjects with SARS-CoV-2 infection did not report any cases among those submitted to immunotherapy [10]. Thus, patients may be less inclined towards grave infections, but are at risk of a cytokine release syndrome that would aggravate a SARS-CoV-2 infection [70-72]. PD-1 blockade is anticipated to reduce the development of sepsis secondary to severe pneumonia and excessive inflammatory response syndrome in COVID-19 patients, by reversing sepsis-associated $\mathrm{T}$ cell depletion.

However, the management must be cautiously calculated on a case-by-case scenario, given the possible augmentation in the risk of side-effects or death from the SARS-CoV-2 infection [73]. Checkpoint inhibitors (ICIs) appear to be more supportable than other chemotherapeutic drugs [74,75]. If the studies on camrelizumab in patients with SARS-CoV-2 infection give comforting results [61], the use of this drug could be an important element for the treatment of the disease in many neoplastic patients.

A different substance that seems to have surprising implications for subjects with SARS-CoV-2 infection is ibrutinib. Ibrutinib is a powerful covalent inhibitor of Bruton tyrosine kinase (BTK). Ibrutinib is also a strong reversible inhibitor of hematopoietic cell kinase (HCK).

The possibility for ibrutinib to reduce lung damage, pulmonary inflammatory cytokines, and death has in the past been established in a lethal flu experimental animal model, in which animals were challenged with an intranasal inoculum of H1N1 influenza virus. Control animals presented with respiratory failure, with histological and Computed Tomography (CT) features coherent with relevant lung damage, in contrast to the animals treated with ibrutinib. Non-treated animals died, while those treated with ibrutinib recuperated and regained their weight after an initial loss, and all survived [76].

Some experimental investigations have allowed elucidation of the mechanisms of action of ibrutinib. It was demonstrated that BTK, and its activator HCK, are implicated in Toll-like receptor (TLR) mediated signaling [77-79]. Both BTK and HCK are stimulated by Myeloid differentiation factor 
88 (MyD88), a TLR-adaptor protein that acts on all Toll receptors excluding TLR3 in response to viruses, including coronaviruses [80]. ATII cells have TLRs, as do the alveolar macrophages that regulate inflammatory responses. As central elements of TLR/MYD88 signaling, BTK and HCK can control inflammatory cytokine generation via Extracellular signal-regulated kinases (ERK)1/2 [81].

In a transgenic animal model, stimulation of HCK caused serious pulmonary inflammation and an increase of the innate immune response, especially in older animals [82]. Augmented concentrations of TNF-a were found in the bronchoalveolar lavage fluids of these animals. The pulmonary alterations evidenced in these mice looked very similar to those reported in the lungs of subjects with SARS-CoV-2 infection, which presented with fibrin exudation with alveolar infiltration of monocytes and macrophages [83].

Treon et al. tried to elucidate the effect of ibrutinib in SARS-CoV-2 subjects [84]. They evaluated 300 Waldenstrom's macroglobulinemia (WM) patients treated with a BTK-inhibitor. They investigated six subjects receiving ibrutinib (five patients received $420 \mathrm{mg} /$ day; one patient received $140 \mathrm{mg} /$ day) who were diagnosed with SARS-CoV-2 infection. Their median time with SARS-CoV-2 correlated symptoms prior to diagnostic analysis was five days. All six subjects had fever and a cough as prodromal signs. The five patients on ibrutinib at $420 \mathrm{mg} /$ day had no dyspnea, and did not need hospitalization. Their course was characterized by constant improvement, and disappearance of SARS-CoV-2 correlated symptoms. The subject on treatment with ibrutinib $140 \mathrm{mg} /$ day presented with increasing dyspnea and hypoxia, provoking hospitalization. Chest CT demonstrated bilateral ground glass opacities. This induced a hold on ibrutinib administration, with a severe worsening of hypoxia [84].

Although the study included only a small series of patients, it surely offers interesting possibilities. Subjects on ibrutinib may benefit from maintenance of their treatment, despite the presence of SARS-CoV-2 infection, although it will be essential to confirm these data in other subjects on BTK-inhibitors, including CLL patients.

Low-dose selinexor will be evaluated in a randomized clinical trial for hospitalized subjects with severe SARS-CoV-2 infection (NCT04349098). This oral drug has been approved for the treatment of subjects with relapsed/refractory multiple myeloma [85]. It is a selective inhibitor of nuclear export (SINE) compound that acts on cellular protein Exportin (XPO1). The protein supports the transportation of numerous essential proteins from the nucleus to the cytoplasm, increasing the actions of pro-inflammatory transcription factors. SINE elements have also shown the capability to reduce the proliferation of several viruses, such as RNA viruses, influenza, and respiratory syncytial virus, in vitro and in vivo. Moreover, these elements have been able to provoke anti-inflammatory and anti-viral activities in several animal models, including showing effects in respiratory infections. Finally, SINE compounds have been demonstrated to be able to inhibit relevant host protein interactions with SARS-CoV-2 [86].

\section{The Management of Cancer Patients with SARS-CoV2 Infection}

The present SARS-CoV-2 pandemic is modifying how we face tumors in several ways. In the context of SARS-CoV-2, greater importance is being placed upon the therapy of cancer patients who may be at augmented risk for having serious and potentially fatal events [87].

Cytotoxic therapies employed for hematological malignancies can provoke a reduction of lymphocyte subsets, possibly making subjects more vulnerable to infection $[88,89]$.

Analogous reflections must be formulated for the employment of radiotherapy. This type of treatment may worsen myelosuppression and augment the risk of SARS-CoC-2 infection. Nevertheless, there are several possibilities for radiotherapy timing, and suitable single fraction or short courses of radiation are recommended [90].

Although the effects of viral pandemics on tumor subjects are far from certain, the choice to continue with anti-tumor treatment, including surgery, during the conditions of the SARS-CoV-2 outbreak should be cautiously evaluated given the possibility of immunosuppression, critical respiratory complications, 
or death. An analysis of 34 asymptomatic subjects who undertook diverse elective surgeries during the course of the SARS-CoV-2 incubation period helped to clarify these risks [91]. All 34 subjects developed SARS-CoV-2 pneumonia just after surgery (median time to SARS-CoV-2 onset, 3.5 days), with $44 \%$ requiring ICU admission. Half of these subjects died in the ICU.

However, delaying specific tumor surgeries may be correlated with an augmented risk of progression.

Several solid cancers, such as pancreatic or lung cancer and some hematologic diseases, such as acute leukemia, require urgent therapy. However, other early-stage tumors, such as prostate, cervical, breast, and nonmelanoma skin tumors, may be able to be treated with a certain delay.

Consequently, the risk:benefit ratio of a systemic antitumor therapy has to be evaluated. For each cancer subject, numerous elements, such as performance status, age, comorbidities, and the number of hospital visits required for the therapy, can modify this risk [92].

As a result of the pandemics, elective medical care has been de-prioritized in many places, and a logical framework to evaluate patient prioritization is required. Oncology societies and national authorities have been quick to release guidelines on tumor care during the outbreak [93].

For example, the NHS in England has defined a prioritization of systemic anticancer treatments, as displayed in Table 3.

Table 3. Prioritizing systemic anticancer treatments (extracted and adapted from National Health System England's clinical guide for the management of non-coronavirus patients requiring acute treatment: cancer [94]).

\begin{tabular}{|c|c|}
\hline Priority Level & Treatment \\
\hline 1 & $\begin{array}{l}\text { Curative treatment with high chance of success }(>50 \%) \\
\text { Adjuvant/neoadjuvant treatment which adds at least } 50 \% \text { chance of cure to } \\
\text { surgery/radiotherapy alone/treatment given at relapse }\end{array}$ \\
\hline 2 & $\begin{array}{l}\text { Curative treatment with an intermediate chance of success }(20-50 \%) \\
\text { Adjuvant/neoadjuvant treatment which adds } 20-50 \% \text { chance of cure to surgery/radiotherapy } \\
\text { alone/treatment given at relapse }\end{array}$ \\
\hline 3 & $\begin{array}{l}\text { Curative treatment with a low chance of success }(10-20 \%) \\
\text { Adjuvant/neoadjuvant treatment which adds } 10-20 \% \text { chance of cure to surgery/radiotherapy } \\
\text { alone/treatment given at relapse } \\
\text { Non-curative treatment with a high chance of more than } 1 \text { year extension }(>50 \%)\end{array}$ \\
\hline 4 & $\begin{array}{l}\text { Curative treatment with a very low chance of success }(0-10 \%) \\
\text { Adjuvant/neoadjuvant treatment which adds less than } 10 \% \text { chance of cure to } \\
\text { surgery/radiotherapy alone/treatment given at relapse } \\
\text { Non-curative treatment with an intermediate chance of more than } 1 \text { year extension to life } \\
(15 \% \text { to } 50 \%)\end{array}$ \\
\hline 5 & $\begin{array}{l}\text { Non-curative treatment with a high chance of palliation or temporary tumor control }(>50 \%) \\
\text { and less than } 1 \text { year expected extension to life }\end{array}$ \\
\hline 6 & $\begin{array}{l}\text { Non-curative treatment with an intermediate chance of palliation or temporary tumor } \\
\text { control }(15-50 \%) \text { and less than } 1 \text { year expected extension to life }\end{array}$ \\
\hline
\end{tabular}

Chemotherapy in a local hospital is suggested to decrease population movement. High-dosage chemotherapy or protocols with relevant myelotoxicity should be avoided, while Granulocyte Colony-Stimulating Factor (G-CSF) should be administered. Oral chemotherapy drugs suitable for home-based therapy are preferred, particularly for palliative therapy.

The creation of a mathematical framework might permit a quantitative analysis to balance conflicting risks and support treatment decision making. Incorporation of SARS-CoV-2-correlated risk models into the analysis of randomized trials could guide clinical decisions during this outbreak [95]. 


\section{Conclusions}

SARS-CoV-2 is seriously interfering with tumor therapy, and nullifying attempts to treat cancer patients adequately [96].

The combination of these two health problems, tumors and the outbreak, could become a catastrophe if not correctly handled. Mishandling could affect thousands of lives and lead to wasted time, money, and energy. The ultimate objective of all treatment options is to decrease the damage as much as possible [97].

Moreover, the negative effects of the outbreak on tumor patients are not restrained to direct effects only. This pandemic has reduced the activities of several research centers and oncological clinical units, has stopped patient enrolment into clinical trials, and has halted novel clinical studies. Most trials need supplementary visits and tests, further augmenting the possibility for diffusion of infection. Finally, the amount of new drugs able to be released, both in terms of production and delivery, may be reduced [98].

Careful and judicious management of cancer patients with SARS-Cov2 could guarantee a better outcome for these patients, and a less dramatic impact due to the current pandemic.

Author Contributions: Conceptualization, A.A., C.M., and S.G.; software, A.T. and G.P.; formal analysis, A.A.; data curation, G.P., A.T., and A.A.; writing-original draft preparation, A.A.; writing-review and editing, A.A. and S.G.; All authors have read and agreed to the published version of the manuscript.

Funding: This research received no external funding.

Conflicts of Interest: The authors declare no conflict of interest.

\section{References}

1. Report of the WHO-China Joint Mission on Coronavirus Disease 2019 (COVID-19). 16-24 February 2020. Available online: https://www.who.int/docs/default-source/coronaviruse/who-china-joint-mission-on-covid19-final-report.pdf (accessed on 7 April 2020).

2. Chen, W.; Zheng, R.; Baade, P.D.; Zhang, S.; Zeng, H.; Bray, F.; Jemal, A.; Yu, X.Q.; He, J. Cancer statistics in China, 2015. CA Cancer J. Clin. 2016, 66, 115-132. [CrossRef]

3. Kamboj, M.; Sepkowitz, K.A. Nosocomial infections in patients with cancer. Lancet Oncol. 2009, 10, 589-597. [CrossRef]

4. Ganatra, S.; Hammond, S.P.; Nohria, A. The novel coronavirus disease (COVID-19) threat for patients with cardiovascular disease and cancer. JACC CardioOncol. 2020. [CrossRef] [PubMed]

5. Allegra, A.; Musolino, C.; Tonacci, A.; Pioggia, G.; Gangemi, S. Interactions between the microRNAs and microbiota in cancer development: Roles and therapeutic opportunities. Cancers 2020, 12, 805. [CrossRef] [PubMed]

6. Allegra, A.; Innao, V.; Allegra, A.G.; Ettari, R.; Pugliese, M.; Pulvirenti, N.; Musolino, C. Role of the microbiota in hematologic malignancies. Neth. J. Med. 2019, 77, 67-80.

7. Jazieh, A.-R.; Alenazi, T.H.; Alhejazi, A.; Al Safi, F.; Al Olayan, A. Outcome of oncology patients infected with coronavirus. JCO Glob. Oncol. 2020, 6, 471-475. [CrossRef]

8. Chowell, G.; Ayala, A.; Berisha, V.; Viboud, C.; Schumacher, M. Risk factors for mortality among 2009 A/H1N1 INflUENZA HOSPITALIZATIONs in Maricopa County, Arizona, April 2009 to March 2010. Comput. Math. Methods Med. 2012, 2012,1-8. [CrossRef]

9. Lai, A.G.; Pasea, L.; Banerjee, A.; Denaxas, S.; Katsoulis, M.; Chang, W.H.; Williams, B.; Pillay, D.; Noursadeghi, M.; Linch, D.; et al. Estimating excess mortality in people with cancer and multimorbidity in the COVID-19 emergency. medRxiv 2020. [CrossRef]

10. Liang, W.; Guan, W.; Chen, R.; Wang, W.; Li, J.; Xu, K.; Li, C.; Ai, Q.; Lu, W.; Liang, H.; et al. Cancer patients in SARS-CoV-2 infection: A nationwide analysis in China. Lancet Oncol. 2020, 21, 335-337. [CrossRef]

11. WorldOMeter. COVID-19 Coronavirus Pandemic. 2020. Available online: www.worldometers.info/ coronavirus/ (accessed on 21 March 2010). 
12. Hrusak, O.; Kalina, T.; Wolf, J.; Balduzzi, A.; Provenzi, M.; Rizzari, C.; Rives, S.; del Pozo Carlavilla, M.; Alonso, V.M.E.; Domínguez Pinilla, N.; et al. Flash survey on SARS-CoV-2 infections in pediatric patients on anticancer treatment. Eur. J. Cancer 2020. [CrossRef] [PubMed]

13. Yu, J.; Ouyang, W.; Chua, M.L.K.; Xie, C. SARS-CoV-2 transmission in patients with cancer at a tertiary care hospital in Wuhan, China. JAMA Oncol. 2020, e200980. [CrossRef] [PubMed]

14. Chen, N.; Zhou, M.; Dong, X.; Qu, J.; Gong, F.; Han, Y.; Qiu, Y.; Wang, J.; Liu, Y.; Wei, Y.; et al. Epidemiological and clinical characteristics of 99 cases of 2019 novel coronavirus pneumonia in Wuhan, China: A descriptive study. Lancet 2020, 395, 507-513. [CrossRef]

15. Deng, G.; Yin, M.; Chen, X.; Zeng, F. Clinical determinants for fatality of 44,672 patients with COVID-19. Crit. Care. 2020, 24, 179. [CrossRef] [PubMed]

16. He, W.; Chen, L.; Chen, L.; Yuan, G.; Fang, Y.; Chen, W.; Wu, D.; Liang, B.; Lu, X.; Ma, Y.; et al. COVID-19 in persons with haematological cancers. Leukemia 2020, 1-9. [CrossRef]

17. Palmieri, L.; Andrianou, X.; Barbariol, P.; Bella, A.; Bellino, S.; Benelli, E.; Members of the COVID-19 Surveillance Group. Characteristics of COVID-19 Patients Dying in Italy. Report Based on Available Data on March 20th. 2020. Available online: https://www.epicentro.iss.it/coronavirus/bollettino/Report-COVID2019_20_marzo_eng.pdf (accessed on 20 March 2020).

18. Onder, G.; Rezza, G.; Brusaferro, S. Case-fatality rate and characteristics of patients dying in relation to COVID-19 in Italy. JAMA 2020. [CrossRef] [PubMed]

19. Balduzzi, A.; Brivio, E.; Rovelli, A.; Rizzari, C.; Gasperini, S.; Melzi, M.L.; Conter, V.; Biondi, A. Lessons after the early management of the COVID-19 outbreak in a paediatric transplant and haemato-oncology centre embedded within a COVID-19 dedicated hospital in Lombardia, Italy. Bone Marrow Transplant. 2020, 1-6. [CrossRef]

20. Miyashita, H.; Mikami, T.; Chopra, N.; Yamada, T.; Chernyavsk, S.; Dahlia Rizk, D.; Cruz, C. Do patients with cancer have a poorer prognosis of COVID-19? An experience in New York City. Ann. Oncol. 2020. [CrossRef]

21. Feng, R.-M.; Zong, Y.-N.; Cao, S.-M.; Xu, R.-H. Current cancer situation in China: Good or bad news from the 2018 global cancer statistics? Cancer Commun. 2019, 39, 22. [CrossRef]

22. Dai, M.; Liu, D.; Liu, M.; Zhou, F.; Li, G.; Chen, Z.; Zhang, Z.; You, H.; Wu, M.; Zheng, Q.; et al. Patients with cancer appear more vulnerable to SARS-COV-2: A multi-center study during the COVID-19 outbreak. Cancer Discov. 2020. CD-20-0422. [CrossRef]

23. Bhatraju, P.K.; Ghassemieh, B.J.; Nichols, M.; Kim, R.; Jerome, K.R.; Nalla, A.K.; Greninger, A.L.; Pipavath, S.; Wurfel, M.M.; Evans, L.; et al. Covid-19 in critically ill patients in the Seattle region-Case series. N. Engl. J. Med. 2020. [CrossRef]

24. Seneff, M.G.; Zimmerman, J.E.; Knaus, W.A.; Wagner, D.P.; Draper, E.A. Predicting the duration of mechanical ventilation. The importance of disease and patient characteristics. Chest 1996, 110, 469-479. [CrossRef] [PubMed]

25. ICNARC COVID-19 Study Case Mix Programme Database. ICNARC Report on COVID-19 in Critical Care. 2020. Available online: https://www.icnarc.org/About/Latest-News/2020/04/04/Report-On2249-PatientsCritically-Ill-With-Covid-19 (accessed on 27 March 2020).

26. Janka, G.E.; Lehmberg, K. Hemophagocytic syndromes-An update. Blood Rev. 2014, 28, 135-142. [CrossRef] [PubMed]

27. Hu, Z.; Song, C.; Xu, C.; Jin, G.; Chen, Y.; Xu, X.; Ma, H.; Chen, W.; Lin, Y.; Zheng, Y.; et al. Clinical characteristics of 24 asymptomatic infections with COVID-19 screened among close contacts in Nanjing, China. Sci. China Life Sci. 2020, 63, 706-711. [CrossRef]

28. Zhou, P.; Yang, X.L.; Wang, X.G.; Hu, B.; Zhang, L.; Zhang, W.; Si, H.-R.; Zhu, Y.; Li, B.; Huang, C.-L.; et al. A pneumonia outbreak associated with a new coronavirus of probable bat origin. Nature 2020, 579, 270. [CrossRef] [PubMed]

29. Jia, X.; Yin, C.; Lu, S.; Chen, Y.; Liu, Q.; Bai, J.; Lu, Y. Two things about COVID-19 might need attention. Preprints 2020, 2020020315. [CrossRef]

30. Yang, J.; Li, H.; Hu, S.; Zhou, Y. ACE2 correlated with immune infiltration serves as a prognostic biomarker in endometrial carcinoma and renal papillary cell carcinoma: Implication for COVID-19. Aging (Albany NY) 2020, 12, 6518-6535. [CrossRef]

31. Zhang, J.J.; Dong, X.; Cao, Y.Y.; Yuan, Y.-D.; Yang, Y.-B.; Yan, Y.-Q.; Akdis, C.A.; Gao, Y.-D. Clinical characteristics of 140 patients infected with SARS-CoV-2 in Wuhan, China. Allergy 2020. [CrossRef] 
32. Bao, L.; Deng, W.; Huang, B.; Gao, H.; Liu, J.; Ren, L.; Wei, Q.; Yu, P.; Xu, Y.; Qi, F.; et al. The pathogenicity of 2019 novel coronavirus in hACE2 transgenic mice. Nature 2020. [CrossRef]

33. Yang, X.H.; Deng, W.; Tong, Z.; Liu, Y.-X.; Zhang, L.-F.; Zhu, H.; Gao, H.; Huang, L.; Liu, Y.-L.; Ma, C.-M.; et al. Mice transgenic for human angiotensin-converting enzyme 2 provide a model for SARS coronavirus infection. Comp. Med. 2007, 57, 450-459.

34. Kong, Q.; Xiang, Z.; Wu, Y.; Gu, Y.; Guo, J.; Geng, F. Analysis of the susceptibility of lung cancer patients to SARS-CoV-2 infection. Mol. Cancer. 2020, 19, 80. [CrossRef]

35. Xu, Z.; Shi, L.; Wang, Y.; Zhang, J.; Huang, L.; Zhang, C.; Liu, S.; Zhao, P.; Liu, H.; Zhu, L.; et al. Pathological findings of COVID-19 associated with acute respiratory distress syndrome. Lancet Respir. Med. 2020, 8, 420-422. [CrossRef]

36. Cai, G. Bulk and single-cell transcriptomics identify tobacco-use disparity in lung gene expression of ACE2, the receptor of 2019-nCov. medRxiv 2020. [CrossRef]

37. Guan, W.-J.; Ni, Z.-Y.; Hu, Y.; Liang, W.-H.; Ou, C.-Q.; He, J.-X.; Liu, L.; Shan, H.; Lei, C.-L.; Hui, D.S.C.; et al. China medical treatment expert group for Covid-19. Clinical characteristics of 2019 novel coronavirus infection in China. N. Engl. J. Med. 2020, 382, 1708-1720. [CrossRef]

38. Xia, Y.; Jin, R.; Zhao, J.; Li, W.; Shen, H. Risk of COVID-19 for patients with cancer. Lancet Oncol. 2020, 21, e180. [CrossRef]

39. Schreiber, R.D.; Old, L.J.; Smyth, M.J. Cancer immunoediting: Integrating immunity's roles in cancer suppression and promotion. Science 2011, 331, 1565-1570. [CrossRef] [PubMed]

40. Ryzhakov, G.; Lai, C.C.; Blazek, K.; To, K.W.; Hussell, T.; Udalova, I. IL-17 boosts proinflammatory outcome of antiviral response in human cells. J. Immunol. 2011, 187, 5357-5362. [CrossRef] [PubMed]

41. Hou, W.; Jin, Y.-H.; Kang, H.S.; Kim, B.S. Interleukin-6 (IL-6) and IL-17 synergistically promote viral persistence by inhibiting cellular apoptosis and cytotoxic T cell function. J. Virol. 2014, 88, 8479-8489. [CrossRef] [PubMed]

42. Patera, A.C.; Pesnicak, L.; Bertin, J.; Cohen, J.I. Interleukin 17 modulates the immune response to vaccinia virus infection. Virology 2002, 299, 56-63. [CrossRef] [PubMed]

43. Li, J.T.; Melton, A.C.; Su, G.; Hamm, D.E.; LaFemina, M.; Howard, J.; Fang, X.; Bhat, S.; Huynh, K.M.; O'Kane, C.M.; et al. Unexpected role for adaptive $\alpha \beta$ Th17 cells in acute respiratory distress syndrome. J. Immunol. 2015, 195, 87-95. [CrossRef]

44. Ding, P.; Zhang, S.; Yu, M.; Feng, Y.; Long, Q.; Yang, H.; Li, J.; Wang, M. IL-17A promotes the formation of deep vein thrombosis in a mouse model. Int. Immunopharmacol. 2018, 57, 132-138. [CrossRef]

45. Pan, B.; Che, D.; Cao, J.; Shen, J.; Jin, S.; Zhou, Y.; Liu, F.; Gu, K.; Man, Y.; Shang, L.; et al. Interleukin-17 levels correlate with poor prognosis and vascular endothelial growth factor concentration in the serum of patients with non-small cell lung cancer. Biomarkers 2015, 20, 232-239. [CrossRef] [PubMed]

46. Pan, B.; Shen, J.; Cao, J.; Zhou, Y.; Shang, L.; Jin, S.; Cao, S.; Che, D.; Liu, F.; Yu, Y. Interleukin-17 promotes angiogenesis by stimulating VEGF production of cancer cells via the STAT3/GIV signaling pathway in non-small-cell lung cancer. Sci. Rep. 2015, 5, 16053-16066. [CrossRef] [PubMed]

47. Li, C.; Yang, P.; Sun, Y.; Li, T.; Wang, C.; Wang, Z.; Zou, Z.; Yan, Y.; Wang, W.; Wang, C.; et al. IL-17 response mediates acute lung induced by the 2009 pandemic influenza A (H1N1) virus. Cell Res. 2012, 22, 528-538. [CrossRef]

48. Fabre, J.; Giustiniani, J.; Garbar, C.; Antonicelli, F.; Merrouche, Y.; Bensussan, A.; Bagot, M.; Al-Dacak, R. Targeting the tumor microenvironment: The protumor effect of IL-17 related to cancer type. J. Mol. Sci. 2016, 17, 1433. [CrossRef]

49. Righetti, R.F.; Dos Santos, T.M.; Camargo, L.D.N.; Aristóteles, L.R.C.R.B.; Fukuzaki, S.; de Souza, F.C.R.; Santana, F.P.R.; de Agrela, M.V.R.; Cruz, M.M.; Alonso-Vale, M.I.C.; et al. Protective effects of anti-IL17 on acute lung injury induced by LPS in mice. Front. Pharmacol. 2018, 9, 1021. [CrossRef] [PubMed]

50. Mi, S.; Li, Z.; Yang, H.Z.; Liu, H.; Wang, J.P.; Ma, Y.G.; Wang, X.X.; Liu, H.Z.; Sun, W.; Hu, Z.W. Blocking IL-17A promotes the resolution of pulmonary inflammation and fibrosis via TGFbeta1-dependent and -independent mechanisms. J. Immunol. 2011, 187, 3003-3014. [CrossRef]

51. Cafarotti, S. SARS-CoV2 infection and lung cancer patients: The potential role of IL17 target therapy. J. Thorac. Oncol. 2020. [CrossRef] [PubMed]

52. Qu, J.; Yang, R.; Song, L.; Kamel, I.R. Atypical lung feature on chest CT in a lung adenocarcinoma cancer patient infected with COVID-19. Ann. Oncol. 2020. [CrossRef] [PubMed] 
53. Zhu, W.J.; Wang, J.; He, X.H.; Qin, Y.; Yang, S.; Hu, X.S.; Wang, H.Y.; Huang, J.; Zhou, A.P.; Ma, F.; et al. The differential diagnosis of pulmonary infiltrates in cancer patients during the outbreak of the 2019 novel coronavirus disease. Zhonghua Zhong Liu Za Zhi 2020, 42, 305-311. [PubMed]

54. Wei, X.; Su, J.; Yang, K.; Wei, J.; Wan, H.; Cao, X.; Tan, W.; Wang, H. Elevations of serum cancer biomarkers correlate with severity of COVID-19. J. Med. Virol. 2020. [CrossRef] [PubMed]

55. Stockley, R.A.; Shaw, J.; Whitfield, A.G.; Clarke, C.A.; Burnett, D. Effect of cigarette smoking, pulmonary inflammation, and lung disease on concentrations of carcinoembryonic antigen in serum and secretions. Thorax 1986, 41, 17-24. [CrossRef] [PubMed]

56. Hirakata, Y.; Kobayashi, J.; Sugama, Y.; Kitamura, S. Elevation of tumour markers in serum and bronchoalveolar lavage fluid in pulmonary alveolar proteinosis. Eur. Respir. J. 1995, 8, 689-696. [PubMed]

57. Barouchos, N.; Papazafiropoulou, A.; Iacovidou, N.; Vrachnis, N.; Barouchos, N.; Armeniakou, E.; Dionyssopoulou, V.; Mathioudakis, A.G.; Christopoulou, E.; Koltsida, S.; et al. Comparison of tumor markers and inflammatory biomarkers in chronic obstructive pulmonary disease (COPD) exacerbations. Scand. J. Clin. Lab. Investig. 2015, 75, 126132. [CrossRef]

58. Nagy, B., Jr.; Bene, Z.; Fejes, Z.; Heltshe, S.; Reid, D.; Ronan, N.; McCarthy, Y.; Smith, D.; Nagy, A.; Joseloff, E.; et al. Human epididymis protein 4 (he4) levels inversely correlate with lung function improvement (delta fev1) in cystic fibrosis patients receiving ivacaftor treatment. J. Cystic Fibros. 2019, 18, 271-277. [CrossRef] [PubMed]

59. Akil, E.; Bulut, A.; Kaplan, I.; Özdemir, H.H.; Arslan, D.; Aluçlu, M.U. The increase of carcinoembryonic antigen (CEA), high-sensitivity c-reactive protein, and neutrophil/lymphocyte ratio in Parkinson's disease. Neurol. Sci. 2015, 36, 423-428. [CrossRef]

60. Bagaria, B.; Bagaria, A.; Sharma, R.; Sood, S.; Lalwani, S. Significance of correlation between levels of carcinoembryonic antigen and carbohydrate antigen 19-9, carcinoembryonic antigen and c-reactive protein, carcinoembryonic antigen and alpha-1 antitrypsin in gastric and colon cancer patients. Clin. Cancer Investig. J. 2014, 3, 291-298. [CrossRef]

61. American Association for Cancer Research. Cancer Labs Pivot to Battle COVID-19. Cancer Discov. 2020, 10, 634. [CrossRef]

62. Kourie, H.R.; Awada, G.; Awada, A.H. Learning from the 'tsunami' of immune checkpoint inhibitors in 2015. Crit. Rev. Oncol. Hematol. 2016, 101, 213-220. [CrossRef]

63. Atkins, M.B.; Plimack, E.R.; Puzanov, I.; Fishman, M.N.; McDermott, D.F.; Cho, D.C.; Vaishampayan, U.; George, S.; Olencki, T.E.; Tarazi, J.C.; et al. Axitinib in combination with pembrolizumab in patients with advanced renal cell cancer: A non-randomised, open-label, dose-finding, and dose-expansion phase $1 \mathrm{~b}$ trial. Lancet Oncol. 2018, 19, 405-415. [CrossRef]

64. Motzer, R.J.; Escudier, B.; McDermott, D.F.; George, S.; Hammers, H.J.; Srinivas, S.; Tykodi, S.S.; Sosman, J.A.; Procopio, G.; Plimack, E.R.; et al. Nivolumab versus everolimus in advanced renal-cell carcinoma. N. Engl. J. Med. 2015, 373, 1803-1813. [CrossRef]

65. Schmid, P.; Adams, S.; Rugo, H.S.; Schneeweiss, A.; Barrios, C.H.; Iwata, H.; Diéras, V.; Hegg, R.; Im, S.-A.; Wright, G.S.; et al. Atezolizumab and nab-paclitaxel in advanced triple-negative breast cancer. N. Engl. J. Med. 2018, 379, 2108-2121. [CrossRef] [PubMed]

66. El-Khoueiry, A.B.; Sangro, B.; Yau, T.; Crocenzi, T.S.; Kudo, M.; Hsu, C.; Kim, T.-Y.; Choo, S.-P.; Trojan, J.; Welling Rd, T.H.; et al. Nivolumab in patients with advanced hepatocellular carcinoma (CheckMate 040): An open-label, non-comparative, phase 1/2 dose escalation and expansion trial. Lancet 2017, 389, 2492-2502. [CrossRef]

67. Ostios-Garcia, L.; Faig, J.; Leonardi, G.C.; Adeni, A.E.; Subegdjo, S.J.; Lydon, C.A.; Rangachari, D.; Huberman, M.S.; Sehgal, K.; Shea, M.; et al. Safety and efficacy of PD-1 inhibitors among HIV-positive patients with non-small cell lung cancer. J. Thorac. Oncol. 2018, 13, 1037-1042. [CrossRef]

68. Picchi, H.; Mateus, C.; Chouaid, C.; Besse, B.; Marabelle, A.; Michot, J.M.; Champiat, S.; Voisin, A.L.; Lambotte, O. Infectious complications associated with the use of immune checkpoint inhibitors in oncology: Reactivation of tuberculosis after anti PD-1 treatment. Clin. Microbiol. Infect. 2018, 24, 216-218. [CrossRef] [PubMed]

69. Johnson, D.B.; McDonnell, W.J.; Gonzalez-Ericsson, P.I.; Al-Rohil, R.; Mobley, B.C.; Salem, J.-E.; Wang, D.Y.; Sanchez, V.; Wang, Y.; Chastain, C.A.; et al. A case report of clonal EBV-like memory CD4 ${ }^{+} \mathrm{T}$ cell activation in fatal checkpoint inhibitor-induced encephalitis. Nat. Med. 2019, 25, 1243-1250. [CrossRef] 
70. Rassy, E.E.; Assi, T.; Rizkallah, J.; Kattan, J. Diffuse edema suggestive of cytokine release syndrome in a metastatic lung carcinoma patient treated with pembrolizumab. Immunotherapy 2017, 9, 309-311. [CrossRef]

71. Bersanelli, M. Controversies about COVID-19 and anticancer treatment with immune checkpoint inhibitors. Immunotherapy 2020. [CrossRef]

72. Mehta, P.; McAuley, D.F.; Brown, M.; Sanchez, E.; Tattersall, R.S.; Manson, J.J. COVID-19: Consider cytokine storm syndromes and immunosuppression. Lancet 2020, 395, 1033-1034. [CrossRef]

73. NHS. Clinical Guide for the Management of Cancer Patients During the Coronavirus Pandemic. 2020. Available online: www.england.nhs.uk/coronavirus/publication/specialty-guides/ (accessed on 17 March 2020).

74. Kattan, J.; Kattan, C.; Assi, T. Do checkpoint inhibitors compromise the cancer patients' immunity and increase the vulnerability to COVID-19 infection? Immunotherapy 2020, 12, 351-354. [CrossRef]

75. Davis, A.P.; Boyer, M.; Lee, J.H.; Kao, S.C. COVID-19: The use of immunotherapy in metastatic lung cancer. Immunotherapy 2020. [CrossRef]

76. Florence, J.M.; Krupa, A.; Booshehri, L.M.; Davis, S.A.; Matthay, M.A.; Kurdowska, A.K. Inhibiting Bruton's tyrosine kinase rescues mice from lethal influenza induced acute lung injury. Am. J. Physiol. Lung Cell Mol. Physiol. 2018, 315, L52-L58. [CrossRef] [PubMed]

77. Jeffries, C.A.; Doyle, S.; Brunner, C.; Dunne, A.; Brint, E.; Wietek, C.; Walch, E.; Wirth, T.; O'Neill, L.A.J. Bruton's tyrosine kinase is a Toll/interleukin-1 receptor domain-binding protein that participates in nuclear factor $\mathrm{kB}$ activation by Toll-like receptor 4. J. Biol. Chem. 2003, 278, 26258-26264. [CrossRef] [PubMed]

78. Yang, G.; Zhou, Y.; Liu, X.; Xu, L.; Cao, Y.; Manning, R.J.; Patterson, C.J.; Buhrlage, S.J.; Gray, N.; Tai, Y.-T.; et al. A mutation in MYD88 (L265P) supports the survival of lymphoplasmacytic cells by activation of Bruton tyrosine kinase in Waldenström macroglobulinemia. Blood 2013, 122, 1222-1232. [CrossRef] [PubMed]

79. Yang, G.; Buhrlage, S.; Tan, L.; Liu, X.; Chen, J.; Xu, L.; Tsakmaklis, N.; Chen, J.G.; Patterson, C.J.; Brown, J.R.; et al. HCK is a survival determinant transactivated by mutated MYD88, and a direct target of ibrutinib. Blood 2016, 127, 3237-3252. [CrossRef] [PubMed]

80. Wang, Y.; Liu, L. The membrane protein of severe acute respiratory syndrome coronavirus functions as a novel cytosolic pathogen-associated molecular pattern to promote beta interferon induction via a toll-like-receptor-related TRAF3-independent mechanism. mBio 2016, 7, e01872-15. [CrossRef]

81. Chen, J.G.; Liu, X.; Munshi, M.; Xu, L.; Tsakmaklis, N.; Demos, M.G.; Kofides, A.; Guerrera, M.L.; Chan, G.G.; Patterson, C.J.; et al. BTK ${ }^{\text {Cys481Ser }}$ drives ibrutinib resistance via ERK1/2 and protects BTK ${ }^{\text {wild-type }}$ MYD88-mutated cells by a paracrine mechanism. Blood 2018, 131, 2047-2059. [CrossRef]

82. Ernst, M.; Inglese, M.; Scholz, G.M.; Harder, K.W.; Clay, F.J.; Bozinovski, S.; Waring, P.; Darwiche, R.; Kay, T.; Sly, P.; et al. Constitutive activation of the SRC family kinase HCK results in spontaneous pulmonary inflammation and an enhanced innate immune response. J. Exp. Med. 2002, 196, 589-604. [CrossRef]

83. Yao, X.H.; Li, T.Y.; He, Z.C.; Ping, Y.F.; Liu, H.W.; Yu, S.C.; Mou, H.M.; Wang, L.H.; Zhang, H.R.; Fu, W.J.; et al. A pathological report of three COVID-19 cases by minimally invasive autopsies. Zhonghua Bing Li Xue Za Zhi 2020, 49, E009.

84. Treon, S.P.; Castillo, J.; Skarbnik, A.P.; Soumerai, J.D.; Ghobrial, I.M.; Guerrera, M.L.; Meid, K.E.; Yang, G. The BTK-inhibitor ibrutinib may protect against pulmonary injury in COVID-19 infected patients. Blood 2020. [CrossRef]

85. Allegra, A.; Innao, V.; Allegra, A.G.; Leanza, R.; Musolino, C. Selective inhibitors of nuclear export in the treatment of hematologic malignancies. Clin. Lymphoma Myeloma Leuk. 2019, 19, 689-698. [CrossRef]

86. Karyopharm Therapeutics Inc. Karyopharm to Evaluate Low Dose Selinexor as a Potential Treatment for Hospitalized Patients with COVID-19; Karyopharm Therapeutics Inc.: Newton, MA, USA, 2020. Available online: https://bit.ly/2VftoVw (accessed on 7 April 2020).

87. Ueda, M.; Martins, R.; Hendrie, P.C.; McDonnell, T.; Crews, J.R.; Wong, T.L.; McCreery, B.; Jagels, B.; Crane, A.; Byrd, D.R.; et al. Managing cancer care during the COVID-19 pandemic: Agility and collaboration toward a common goal. J. Natl. Compr. Cancer Netw. 2020, 18, 366-369. [CrossRef]

88. UK Coronavirus Cancer Monitoring Project Team. The UK Coronavirus cancer monitoring project: Protecting patients with cancer in the era of COVID-19. Lancet Oncol. 2020, 21, 622-624. [CrossRef]

89. Kutikov, A.; Weinberg, D.S.; Edelman, M.J.; Horwitz, E.M.; Uzzo, R.G.; Fisher, R.I. A war on two fronts: Cancer care in the time of COVID-19. Ann. Intern. Med. 2020, M20-1133. [CrossRef] [PubMed] 
90. Zhao, Z.; Yang, C.; Li, C. Strategies for patient with cancer during COVID-19 pandemic. Asia Pac. J. Clin. Oncol. 2020. [CrossRef] [PubMed]

91. Lei, S.; Jiang, F.; Su, W.; Chen, C.; Chen, J.; Mei, W.; Zhan, L.Y.; Jia, Y.; Zhang, L.; Liu, D.; et al. Clinical characteristics and outcomes of patients undergoing surgeries during the incubation period of COVID-19 infection. EClinicalMedicine 2020, 100331. [CrossRef] [PubMed]

92. Zhou, W.; Liu, Y.; Tian, D.; Wang, C.; Wang, S.; Cheng, J.; Hu, M.; Fang, M.; Gao, Y. Potential benefits of precise corticosteroids therapy for severe 2019-nCoV pneumonia. Signal. Transduc. Target. Ther. 2020, 5, 18. [CrossRef] [PubMed]

93. Emanuel, E.J.; Persad, G.; Upshur, R.; Thome, B.; Parker, M.; Glickman, A.; Zhang, C.; Boyle, C.; Smith, M.; Phillips, J.P. Fair allocation of scarce medical resources in the time of COVID-19. N. Engl. J. Med. 2020. [CrossRef]

94. COVID-19 Rapid Guideline: Delivery of Systemic Anticancer Treatments. NICE Guideline. Available online: https://www.nice.org.uk/guidance/ng161/chapter/6-Prioritising-systemic-anticancer-treatments (accessed on 9 June 2020).

95. Tabrizi, S.; Trippa, L.; Cagney, D.; Tanguturi, S.; Ventz, S.; Fell, G.; Wen, P.Y.; Alexander, B.M.; Rahman, R. A quantitative framework for modeling COVID-19 risk during adjuvant therapy using published randomized trials of glioblastoma in the elderly. Neuro-Oncology 2020. [CrossRef] [PubMed]

96. Blandino, G. Cancer at the time of the COVID-19 hurricane. J. Exp. Clin. Cancer Res. 2020, 39, 74. [CrossRef] [PubMed]

97. Akbarzadeh, M.A.; Hosseini, M.S. Implications for cancer care in Iran during COVID-19 pandemic. Radiother. Oncol. 2020. [CrossRef] [PubMed]

98. Mooney, M.; McCaskill-Stevens, W. Memorandum: Interim Guidance for Patients on Clinical Trials Supported by the NCI Cancer Therapy Evaluation Program and the NCI Community Oncology Research Program (NCORP); Public Health Service, U.S. Department of Health and Human Services: Washington, DC, USA, 13 March 2020. Available online: www.ncicirb.org/system/files/Interim_Guidance_Clinical_Trial_Activities_Affected_by_ Novel_Coronavirus_3-13-2020_0.pdf (accessed on 18 March 2020).

(C) 2020 by the authors. Licensee MDPI, Basel, Switzerland. This article is an open access article distributed under the terms and conditions of the Creative Commons Attribution (CC BY) license (http://creativecommons.org/licenses/by/4.0/). 